"Przegląd Prawa Konstytucyjnego"

Nr 1 (13)/2013 ------

\title{
Recenzja
}

\section{Sławomir Patyra, Mechanizmy racjonalizacji procesu ustawodawczego $w$ Polsce w zakresie rządowych projektów ustaw, Wydawnictwo Adam Marszałek, Toruń 2012, ss. 348}

Recenzowana książka jest pierwszym w Polsce opracowaniem dotyczącym bezpośrednio wpływu rządu na przebieg postępowania ustawodawczego na gruncie aktualnych polskich rozwiązań konstytucyjnych. Autor podkreśla, iż brak kompleksowej monografii ujmującej tę tematykę w znacznej mierze przesądził o wyborze tematu prezentowanej publikacji. Zagadnienie to pozostaje równocześnie w kręgu zainteresowań Sławomira Patyry, który ma w swoim dorobku szereg publikacji poświęconych problematyce współczesnych ustrojów państwowych, ze szczególnym uwzględnieniem statusu ustrojowego władzy wykonawczej oraz procesu ustawodawczego.

W bardzo ciekawym i wyczerpującym wstępie publikacji odnajdujemy podstawowe założenia pracy. Zdaniem Autora, mamy współcześnie do czynienia $\mathrm{z}$ redefinicją ustawy, bowiem nie jest już ona traktowana wyłącznie jako akt w pełni suwerennej decyzji parlamentu. Wzrastający wpływ władzy wykonawczej na proces ustawodawczy widoczny jest przede wszystkim w obrębie państw należących do Unii Europejskiej. Taki stan nie jest jednak negatywnie oceniany przez Autora. Wręcz przeciwnie, S. Patyra uznaje go za konsekwencję rozwoju demokratycznego państwa prawnego.

Zdaniem Autora, zakres oddziaływania rządu na ustawodawstwo determinuje efektywność prowadzenia polityki państwa. Znaczący udział rządu w kształtowaniu normatywnej treści ustawy na poszczególnych etapach drogi ustawodawczej Autor określa jako racjonalizację procesu ustawodawczego, przejawiającą się w postaci wzmocnienia mechanizmów powiązań pozytywnych w stosunkach między legislatywą o egzekutywą. Główną tezę 
publikacji stanowi stwierdzenie, iż Konstytucja z 1997 r., powierzając Radzie Ministrów wiodącą rolę w zakresie prowadzenia polityki zagranicznej i wewnętrznej, nie wyposażyła jej w wystarczająco skuteczne narzędzia oddziaływania na przebieg postępowania ustawodawczego i w konsekwencji na treść normatywną ostatecznie przyjmowanej ustawy.

Bezpośrednią konsekwencją przedstawionych we wstępie założeń są struktura i warstwa merytoryczna pracy. Kluczowym zagadnieniem pierwszego rozdziału jest kwestia racjonalizacji systemów rządów parlamentarnych. Autor przedstawia podstawy tej koncepcji ustrojowej, przeprowadzając także analizę prawnoporównawczą w zakresie przejawów racjonalizowania procesu prawotwórczego poprzez wzmocnienie wpływu rządu na jego przebieg w wybranych państwach europejskich. Rys historyczny, jakim dodatkowo posługuje się Autor, znacznie poszerza wiedzę odbiorcy i stanowi tło rozważań będących głównym przedmiotem zainteresowania Autora.

W kolejnych dwóch rozdziałach Autor przedstawia zakres udziału Rady Ministrów w sejmowym postępowaniu ustawodawczym dotyczącym rządowych projektów ustaw. Rozdział drugi poświęcony został inicjatywie ustawodawczej Rady Ministrów, będącej zdaniem Autora jednym z zasadniczych instrumentów prowadzenia polityki w państwie prawnym. Rządowe prawo inicjatywy ustawodawczej jest jednocześnie warunkiem istnienia systemu rządów parlamentarnych. Rozdział ten ma tylko pozornie charakter podręcznikowy, systematyzujący wiedzę na temat regulacji inicjatywy ustawodawczej w polskim systemie prawnym. Niezwykle dokładnie Autor analizuje bowiem praktykę i konsekwencje tej regulacji, a także ewolucję normatywnego modelu rządowego postępowania poprzedzającego wykonanie inicjatywy ustawodawczej w dotychczasowym okresie obowiązywania Konstytucji z 1997 r.

Rozdział trzeci poświęcony jest rządowym projektom ustaw w toku postępowania legislacyjnego w Sejmie. Rozważania Autora na temat wpływu rządu na postępowanie legislacyjne w Sejmie nie ograniczają się do sfery korekty treściowej projektu poprzez wnoszenie doń poprawek, ale obejmują także możliwości modyfikowania przez rząd trybu prac Sejmu nad ustawą poprzez nadawanie projektom klauzuli pilności.

Rozdział czwarty różni się zasadniczo od wcześniejszych, mających charakter analityczno-wyjaśniający. Został on bowiem poświęcony propono- 
wanym przez Autora mechanizmom zwiększenia wpływu Rady Ministrów na proces prawotwórczy. Propozycje te są spójne, w całości bazujące na założeniu, że im większy zakres oddziaływania rządu na ustawodawstwo, tym większa efektywność prowadzenia polityki państwa. Najciekawsze propozycje Autora odnoszą się do sfery konstytucyjnej i do organizacji wewnątrz rządowego procesu legislacyjnego.

W sferze konstrukcji konstytucyjnych Autor postuluje zwiększenie zakresu konstytucjonalizacji sejmowego procesu legislacyjnego, poprzez przeniesienie na ten grunt części regulacji regulaminowej. Zdaniem Autora, ograniczyłoby to możliwość zbyt daleko idącej ingerencji Izby w treść projektów rządowych i przyczyniło się do zwiększenia dyscypliny i efektywności postępowania legislacyjnego. Kolejne propozycje dotyczą połączenia rządowego projektu ustawy z wnioskiem o udzielenie Radzie Ministrów wotum zaufania, ograniczenia swobody prezydenta Rzeczypospolitej w dysponowaniu prawem do odmowy wydawania rozporządzeń z mocą ustawy oraz przyznania Radzie Ministrów prawa do wydawania rozporządzeń z mocą ustawy.

W sferze organizacji wewnątrz rządowego procesu legislacji Autor opowiada się przede wszystkim za wzmocnieniem mechanizmów służących centralizacji rządowych procedur prelegislacyjnych. Autor uzupełnia swoje założenie o stwierdzenie, że wzmocnienie wpływu rządu na legislację może wywołać efekt racjonalizujący proces ustawodawczy tylko o tyle, o ile podwyższeniu ulegnie jednocześnie jakość parlamentarnej drogi ustawodawczej. To natomiast może nastąpić poprzez centralizację postępowania wewnątrzrządowego, które zapewni spójność i harmonijność realizacji programu legislacyjnego w rządzie.

Trudno przecenić wartość prezentowanej publikacji, która stanie się bardzo ważnym głosem w nieuniknionej debacie na temat racjonalizacji systemu rządów parlamentarnych w Polsce. Zauważyć jednak należy, już same założenia Autora mogą spotkać się z krytyką tych, którzy postulują pozostanie przy modelu zakładającym dominujący wpływ legislatywy na kształtowanie polityki państwa oraz przy sztywnym podziale władz. Jednakże za tezą Autora o potrzebie racjonalizacji polskiego systemu stoją przede wszystkim względy praktyczne. Znikomy wpływ Rady Ministrów na przebieg procesu ustawodawczego, szczególnie w przypadku, gdy organ ten jest 
autorem większości projektów ustawodawczych, z pewnością utrudnia prowadzenie spójnej polityki państwa.

Dość wymagający język, jakim posługuje się Autor, i wartość merytoryczna rozważań mogą okazać się nieco trudne w percepcji dla nieprzygotowanego czytelnika. Niemniej jednak należy zdecydowanie polecić zmierzenie się z prezentowaną lekturą.

Piotr Benedykt Zientarski

(Senat RP) 